\title{
Comparing Well-Defined Manganese, Iron, Cobalt, and Nickel Ketone Hydro- silylation Catalysts
}

\author{
Ryan J. Trovitch* \\ Department of Chemistry \& Biochemistry, Arizona State University, Tempe, AZ 85287, USA \\ Fax +1(480)9652747; E-mail: ryan.trovitch@asu.edu \\ Received: 01.03.2014; Accepted after revision: 26.03.2014
}

\begin{abstract}
A brief review of manganese-catalyzed hydrosilylation is presented along with a personal account of how the design for the

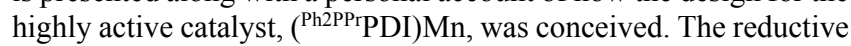
transformations achieved using this catalyst are described and put into further context by comparing the observed activities with those attained for leading late first-row transition-metal catalysts.
\end{abstract}

Key words: catalysis, hydrosilylation, ketones, manganese, ligands

Due to the cost and relative toxicity associated with homogeneous precious metal catalysts, ${ }^{1}$ the search for sustainable alternatives that operate with competitive activities, selectivities, and lifetimes has continued to intensify. ${ }^{2}$ Much of this effort has centered around the development of late first-row transition-metal $(\mathrm{Mn}, \mathrm{Fe}, \mathrm{Co}$, and $\mathrm{Ni}$ ) catalysts, ${ }^{3}$ as these metals are earth-abundant and far less expensive than their precious metal counterparts. ${ }^{4}$ While a wide range of organic transformations have been targeted, ${ }^{5}$ the development of first-row metal hydrosilylation catalysts remains of interest to the polysilane industry $^{2 \mathrm{~b}}$ since platinum catalysts have long been used to prepare silicone coatings and elastomers. ${ }^{6}$ With this in mind, my colleagues and I recently reported the development of a well-defined manganese complex that is capable of mediating ketone hydrosilylation with turnover frequencies (TOF) of up to $76,800 \mathrm{~h}^{-1}$ at ambient temperature. $^{7}$

To put our discovery into perspective, a comparison of manganese-based hydrosilylation catalysts reported to date is essential. The initial mention of manganese-mediated hydrosilylation was published in 1983 by Pratt and Faltynek, ${ }^{8}$ more than 25 years after Speier and co-workers reported $\mathrm{H}_{2} \mathrm{PtCl}_{6}$ to be an effective olefin hydrosilylation catalyst. ${ }^{6 a}$ In this work, $(\mathrm{CO})_{5} \mathrm{MnSiPh}_{3}$ was found to catalyze the reduction of 1-pentene following irradiation with $350 \mathrm{~nm}$ light or heating to $180{ }^{\circ} \mathrm{C} .{ }^{8} \mathrm{~A}$ few years later, Hilal and co-workers reported that $\mathrm{Mn}_{2}(\mathrm{CO})_{10}$ effectively mediates the hydrosilylation of 1-hexene with tertiary silanes under relatively mild conditions $\left(40{ }^{\circ} \mathrm{C}\right) .{ }^{9}$

Since these reports, manganese-based hydrosilylation chemistry has dealt exclusively with the reduction of carbonyl containing substrates (Table 1). In 1995, the Cutler group reported $\left(\mathrm{PPh}_{3}\right)(\mathrm{CO})_{4} \mathrm{MnC}(\mathrm{O}) \mathrm{Me}$ to be an effective

SYNLETT 2014, 25, 000A-000E

Advanced online publication:

DOI: 10.1055/s-0033-1341269; Art ID: st-2014-p0184-sp (C) Georg Thieme Verlag Stuttgart · New York

Imprimatur:

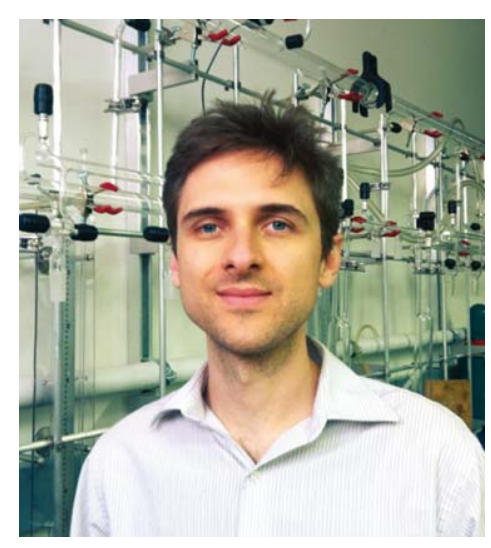

Ryan J. Trovitch received a BSc degree from the Honors Program at King's College (PA) in 2004, where he worked with Prof. Robert L. LaDuca to prepare metal-organic frameworks. After spending a summer at the University of Michigan learning the craft of air-free synthesis from Prof. Mark M. Banaszak-Holl, he went on to receive a $\mathrm{PhD}$ in inorganic chemistry from Cornell University under the direction of Prof. Paul J. Chirik. In 2008, he joined Los Alamos National Laboratory as a postdoctoral research associate and was later appointed as a Glenn T. Seaborg Postdoctoral Fellow. While at LANL, Ryan worked with Dr. Kevin D. John, Dr. John C. Gordon, Dr. Alfred P. Sattleberger (ANL), and Prof. R. Tom Baker (University of Ottawa) to develop transition-metal catalysts for a broad range of organic transformations. Ryan joined the Department of Chemistry \& Biochemistry at Arizona State University as an assistant professor in 2012 , and his group is currently designing sustainable transition-metal catalysts that operate efficiently under mild conditions.

catalyst for the dihydrosilylation of esters to yield the parent ether and siloxane products. ${ }^{10}$ Importantly, this catalyst was found to operate at $24{ }^{\circ} \mathrm{C}$ with TOF of up to 227 $\mathrm{h}^{-1}$. Cutler and co-workers later demonstrated that $\left(\mathrm{PPh}_{3}\right)(\mathrm{CO})_{4} \mathrm{MnC}(\mathrm{O}) \mathrm{Me}$ catalyzes the hydrosilylation of ketone-containing substrates with TOF of up to $1,632 \mathrm{~h}^{-}$ ${ }^{1} .{ }^{11}$ Moreover, this complex has been found to mediate the hydrosilylation of transition-metal acyl complexes. ${ }^{12-14}$ In 1999, Chung and co-workers reported that $\left(\eta^{5}-\right.$ $\left.\mathrm{C}_{10} \mathrm{H}_{9}\right) \mathrm{Mn}(\mathrm{CO})_{3}$ catalyzes the ambient-temperature hydrosilylation of ketones when employing $\mathrm{Ph}_{2} \mathrm{SiH}_{2}$ as the reductant. ${ }^{15}$ Soon after, this investigation was extended to the utilization of the naphthalene-supported complex, $\left[\left(\eta^{6}-\mathrm{C}_{10} \mathrm{H}_{8}\right) \mathrm{Mn}(\mathrm{CO})_{3}\right]\left[\mathrm{BF}_{4}\right]$, which was found to exhibit improved, yet limited, TOF for ketone reduction of up to $99 \mathrm{~h}^{-1}{ }^{16}$

More recently, researchers have investigated the ability of $\mathrm{Mn}_{2}(\mathrm{CO})_{10}$ to catalyze the reduction of $N$-acetylpiperidine to $N$-ethylpiperidine ${ }^{17,18}$ and the hydrosilylation of car- 
Table 1 Carbonyl Hydrosilylation Activities Reported for Well-Defined Manganese Catalysts

\begin{tabular}{|c|c|c|c|c|c|c|}
\hline Catalyst & $\mathrm{mol} \%$ & Temp $\left({ }^{\circ} \mathrm{C}\right)$ & Substrate class & Product class & Silane used & Highest TOF $\left(\mathrm{h}^{-1}\right)$ \\
\hline$\left(\mathrm{PPh}_{3}\right)(\mathrm{CO})_{4} \mathrm{MnC}(\mathrm{O}) \mathrm{Me}$ & $\begin{array}{l}1.5-3.0 \\
2.4\end{array}$ & $\begin{array}{l}24 \\
24\end{array}$ & $\begin{array}{l}\text { esters } \\
\text { ketones }\end{array}$ & $\begin{array}{l}\text { ethers } \\
\text { silyl ethers }\end{array}$ & $\begin{array}{l}\mathrm{PhSiH}_{3} \\
\mathrm{PhMe}_{2} \mathrm{SiH}\end{array}$ & $\begin{array}{l}22710 \\
1,63211\end{array}$ \\
\hline$\left(\eta^{5}-\mathrm{C}_{10} \mathrm{H}_{9}\right) \mathrm{Mn}(\mathrm{CO})_{3}$ & 5.0 & 25 & ketones & silyl ethers & $\mathrm{Ph}_{2} \mathrm{SiH}_{2}$ & 715 \\
\hline$\left[\left(\eta^{6}-\mathrm{C}_{10} \mathrm{H}_{8}\right) \mathrm{Mn}(\mathrm{CO})_{3}\right]\left[\mathrm{BF}_{4}\right]$ & $0.5-5.0$ & 25 & ketones & silyl ethers & $\mathrm{PhMe}_{2} \mathrm{SiH}$ & 9916 \\
\hline $\mathrm{Mn}_{2}(\mathrm{CO})_{10}$ & $\begin{array}{l}1.0 \\
5.0\end{array}$ & $\begin{array}{r}100 \\
25\end{array}$ & $\begin{array}{l}\text { amides } \\
\text { carboxylic acids }\end{array}$ & $\begin{array}{l}\text { amines } \\
\text { disilylacetals }\end{array}$ & $\begin{array}{l}\mathrm{Et}_{3} \mathrm{SiH} \\
\mathrm{Et}_{3} \mathrm{SiH}\end{array}$ & $\begin{array}{l}617 \\
619\end{array}$ \\
\hline$\left(3,5-t-\mathrm{Bu}_{2}\right.$-salen $) \mathrm{MnN}$ & $\begin{array}{l}0.5 \\
0.5\end{array}$ & $\begin{array}{l}80 \\
80\end{array}$ & $\begin{array}{l}\text { aldehydes } \\
\text { ketones }\end{array}$ & $\begin{array}{l}\text { alcohols } \\
\text { alcohols }\end{array}$ & $\begin{array}{l}\mathrm{PhSiH}_{3} \\
\mathrm{PhSiH}_{3}\end{array}$ & $\begin{array}{l}11,76020 \\
58220\end{array}$ \\
\hline ( ${ }^{\text {Ph2PPr }}$ PDI)Mn & $\begin{array}{l}0.01-1.0 \\
1.0\end{array}$ & $\begin{array}{l}25 \\
25-80\end{array}$ & $\begin{array}{l}\text { ketones } \\
\text { esters }\end{array}$ & $\begin{array}{l}\text { silyl ethers } \\
\text { silyl ethers }\end{array}$ & $\begin{array}{l}\mathrm{PhSiH}_{3} \\
\mathrm{PhSiH}_{3}\end{array}$ & $\begin{array}{l}76,8007 \\
187\end{array}$ \\
\hline
\end{tabular}

boxylic acids to yield disilylacetals or their related aldehydes; ${ }^{19}$ however, relatively modest TOF have been realized for both transformations. Chidara and Du have also reported that $\left(3,5-t-\mathrm{Bu}_{2}\right.$-salen) $\mathrm{MnN}$ is capable of mediating the hydrosilylation of 4-nitrobenzaldehyde with a TOF of $11,760 \mathrm{~h}^{-1}$; however, this transformation required heating to $80{ }^{\circ} \mathrm{C} .{ }^{20}$ Further attempts to catalyze the hydrosilylation of benzaldehyde using $1 \mathrm{~mol} \%$ of $\left(3,5-t-\mathrm{Bu}_{2}-\right.$ salen) $\mathrm{MnN}$ at room temperature have taken either 22 hours (in $\mathrm{CDCl}_{3}$ ) or 47 hours (in $\mathrm{C}_{6} \mathrm{D}_{6}$ ) to reach completion. $^{20}$

When we first became interested in developing a manganese-based hydrosilylation catalyst, we hoped to design one that could operate with exceptional activities at mild temperatures. Considering the data in Table 1, along with the benzaldehyde hydrosilylation experiments reported for $\left(3,5-t-\mathrm{Bu}_{2}\right.$-salen) $\mathrm{MnN}^{20}{ }^{20}$ it became clear that $\left(\mathrm{PPh}_{3}\right)(\mathrm{CO})_{4} \mathrm{MnC}(\mathrm{O}) \mathrm{Me}$ remained the best-performing carbonyl hydrosilylation catalyst at ambient temperature. ${ }^{11}$ It has been found that a bulky $\kappa^{3}-N, N, N$-bis(imino)pyridine (or pyridine diimine, PDI) ligand could be used to mimic the coordination environment of mer-car-
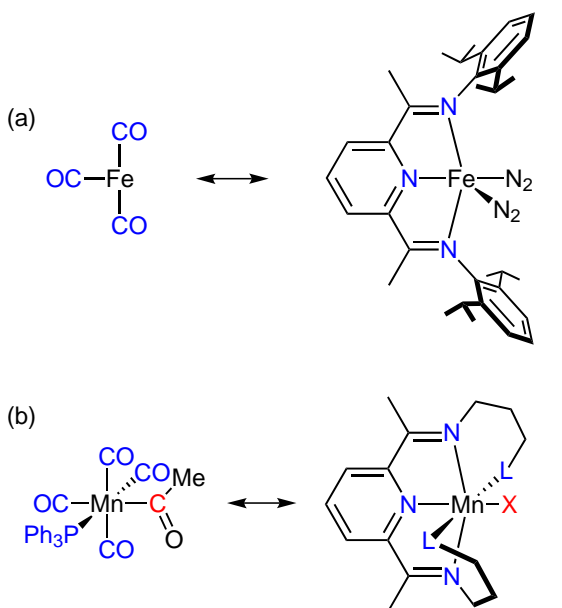

Figure 1 (a) Using a PDI ligand framework to mimic $\mathrm{Fe}(\mathrm{CO})_{3}$. (b) Designing a Mn-based hydrosilylation catalyst with a $\kappa^{5}$-PDI ligand. bonyl ligands, ${ }^{21}$ allowing the preparation of an iron-based hydrogenation catalyst that operates efficiently under mild thermal conditions (Figure 1, a). ${ }^{22,23}$ With this in mind, we believed that a pentadentate PDI chelate could mimic the five neutral ligands of $\left(\mathrm{PPh}_{3}\right)(\mathrm{CO})_{4} \mathrm{MnC}(\mathrm{O}) \mathrm{Me}$ and allow for the preparation of a manganese hydrosilylation catalyst with the general formula $\left(\kappa^{5}-\mathrm{PDI}\right) \mathrm{MnX}$, where $\mathrm{X}$ is an anionic ligand (Figure 1, b).

Furthermore, due to the redox noninnocent nature of PDI ligands, ${ }^{24}$ we recognized that it might be possible to improve upon $\left(\mathrm{PPh}_{3}\right)(\mathrm{CO})_{4} \mathrm{MnC}(\mathrm{O}) \mathrm{Me}$ by designing a formally zerovalent manganese complex that had one or more electrons stored in the $\pi$-system of the ligand (Figure 2 , a). This approach would obviate the need for a dedicated anionic ligand within the catalyst structure, while providing an open site for substrate binding. In order to prepare such a complex, the metalation of ${ }^{\mathrm{Ph} 2 \mathrm{PPr}^{2}} \mathrm{PDI}^{25}$ with (THF $)_{2} \mathrm{MnCl}_{2}$ was conducted, allowing the isolation of $\left(\kappa^{3}-N, N, N-{ }^{\mathrm{Ph} 2 \mathrm{PP}} \mathrm{PDI}\right) \mathrm{MnCl}_{2}$. Reduction of this compound in the presence of excess $\mathrm{Na} / \mathrm{Hg}$ (with or without $1,3,5,7$ cyclooctatetraene present) enabled the preparation of ( $\left.{ }^{\mathrm{Ph} 2 \mathrm{PP}} \mathrm{PDI}\right) \mathrm{Mn}$ (Figure 2, b). ${ }^{7}$ The characterization of this complex by X-ray diffraction, ${ }^{1} \mathrm{H}$ NMR and EPR spec-

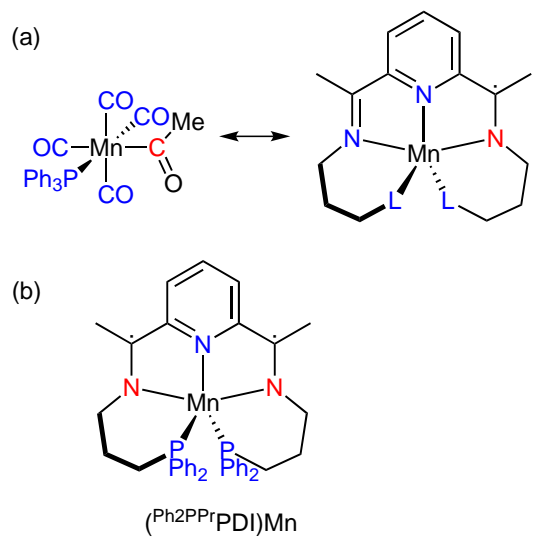

Figure 2 (a) A PDI radical monoanion imitating the ligand field of $\left(\mathrm{PPh}_{3}\right)(\mathrm{CO})_{4} \mathrm{MnC}(\mathrm{O}) \mathrm{Me}$. (b) Electronic structure representation of (Ph2PrPDI)Mn. 
troscopy revealed that $\left({ }^{\mathrm{Ph} 2 \mathrm{PPr} P D I) M n}\right.$ likely consists of a low-spin, divalent manganese center that is coordinated to a singlet PDI dianion. However, the possibility that

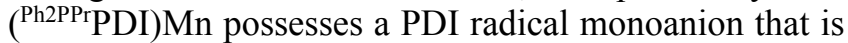
antiferromagnetically coupled to an intermediate-spin manganese(I) center has yet to be ruled out computationally.

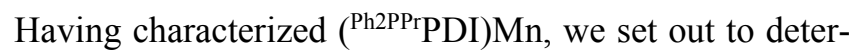
mine whether or not this complex was capable of mediating ketone hydrosilylation. Adding a $1: 1$ ratio of acetophenone and phenylsilane to $1 \mathrm{~mol} \%$ of ( ${ }^{\mathrm{Ph} 2 \mathrm{PP} P \mathrm{PDI}}$ Mn in benzene- $d_{6}$ solution resulted in complete ketone reduction after only four minutes at $25^{\circ} \mathrm{C} .{ }^{7}$ After comparing the activities observed for different silanes, we decided to continue our study with $\mathrm{PhSiH}_{3}$, which enabled the fastest reaction times. We then sought to determine how the electronic and steric properties of the substrate would influence their relative ease of hydrosilylation. Several of the ketones investigated are shown in Scheme $1,[7$ along with the time needed to achieve $>99 \%$ conversion at $25^{\circ} \mathrm{C}$.

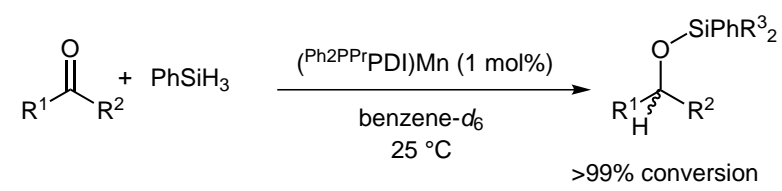

$$
\begin{array}{lll}
\mathrm{R}^{1} & =\mathrm{Me}, \mathrm{R}^{2}=4-\mathrm{Me}_{2} \mathrm{NC}_{6} \mathrm{H}_{4} ; 6 \mathrm{~h} & \mathrm{R}^{1}=\mathrm{R}^{2}=\mathrm{Ph} ; 20 \mathrm{~min} \\
\mathrm{R}^{1}=\mathrm{Me}, \mathrm{R}^{2}=4-\mathrm{MeOC}_{6} \mathrm{H}_{4} ; 25 \mathrm{~min} & \mathrm{R}^{1}=\mathrm{R}^{2}=i-\mathrm{Pr} ; 36 \mathrm{~min} \\
\mathrm{R}^{1}=\mathrm{Me}, \mathrm{R}^{2}=\mathrm{Ph} ; 4 \mathrm{~min} & \mathrm{R}^{1}=\mathrm{R}^{2}=\mathrm{Cy} ; 24 \mathrm{~h} \\
\mathrm{R}^{1}=\mathrm{Me}, \mathrm{R}^{2}=4-\mathrm{FC}_{6} \mathrm{H}_{4} ; 4 \mathrm{~h} & &
\end{array}
$$

Scheme 1 The time required to achieve $>99 \%$ hydrosilylation for series of acetophenones and symmetric ketones (as judged by ${ }^{1} \mathrm{H}$ NMR spectroscopy).

As displayed in Scheme 1, varying the para position of acetophenone significantly extended the time it took for the reaction to reach completion, regardless of whether the substituent was electron donating or electron withdrawing in nature. Extended reaction times were also encountered when investigating the hydrosilylation of sterically demanding substrates such as dicyclohexyl ketone.

Realizing that the activity of ( $\left.{ }^{\mathrm{Ph} 2 \mathrm{PP}} \mathrm{PDI}\right) \mathrm{Mn}$ appeared highly substrate dependent, efforts were made to scale up the hydrosilylation of readily reduced substrates to demonstrate the synthetic utility of our work. In the process, we also sought to enhance the desirability of this transformation by using lower catalyst loadings, eliminating the requirement for solvent, and by adding a substoichiometric amount of $\mathrm{PhSiH}_{3}$ in order to improve atom-efficiency. These efforts are best summarized for the cyclohexanone reductions shown in Scheme $2 .^{7}$ When the catalyst loading was lowered to $0.01 \mathrm{~mol} \%$ in the absence of solvent, the hydrosilylation of cyclohexanone reached completion within five minutes (Scheme 2, a). Although the reagents were mixed at $25^{\circ} \mathrm{C}$, significant heat was generated due to the exothermic nature of the reaction. In turn, the isolated yield was a fairly low $64 \%$ due to evaporation of the reactants, equating to a TOF of 76,800 $\mathrm{h}^{-1}$ (based on product recovery). When a 3:1 ratio of cyclohexanone to phenylsilane was added to $0.33 \mathrm{~mol} \%$ of ( $\left.{ }^{\mathrm{Ph} 2 \mathrm{PP} P D I}\right) \mathrm{Mn}$, complete utilization of the $\mathrm{Si}-\mathrm{H}$ bonds was achieved within four hours to yield $\mathrm{PhSi}(\mathrm{OCy})_{3}$, demonstrating that hydrosilylation could be conducted in an atom-efficient manner at ambient temperature (Scheme 2, b).

(a)
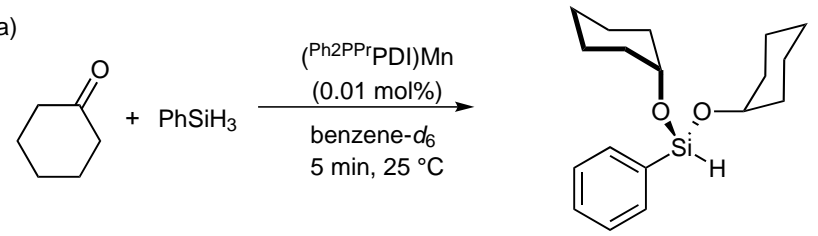

$>99 \%$ conversion $64 \%$ isolated yield TOF $=76,800 \mathrm{~h}^{-1}$

(b)

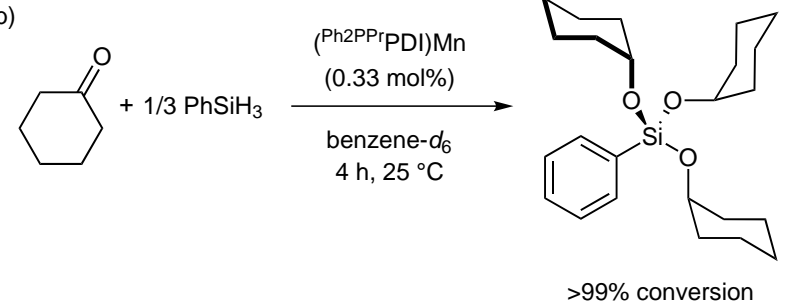

Scheme 2 The hydrosilylation of cyclohexanone (a) at $0.01 \mathrm{~mol} \%$ catalyst loading and (b) at $0.33 \mathrm{~mol} \%$ with 0.33 equiv of $\mathrm{PhSiH}_{3}$.

Finally, we investigated ester hydrosilylation using ( $\left.{ }^{\mathrm{Ph} 2 \mathrm{PP}} \mathrm{PDI}\right) \mathrm{Mn}$ since $\left(\mathrm{PPh}_{3}\right)(\mathrm{CO})_{4} \mathrm{MnC}(\mathrm{O}) \mathrm{Me}$ had been reported to catalyze ester deoxygenation to yield siloxane and the parent ether. ${ }^{10}$ Surprisingly, adding $1 \mathrm{~mol} \%$ of

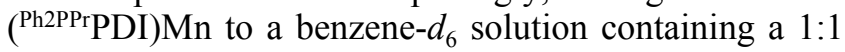
ratio of $\mathrm{MeOAc}$ and $\mathrm{PhSiH}_{3}$ resulted in the formation of four different quaternary silanes after 24 hours at $25^{\circ} \mathrm{C}$ : $\mathrm{PhSi}(\mathrm{OMe})_{3}, \mathrm{PhSi}(\mathrm{OEt})_{3}, \mathrm{PhSi}(\mathrm{OMe})_{2}(\mathrm{OEt})$, and $\mathrm{Ph}-$ $\mathrm{Si}(\mathrm{OEt})_{2}(\mathrm{OMe}){ }^{7}$ Repeating the experiment with $\mathrm{PhSiD}_{3}$ confirmed that each ethoxide substituent was formed following reductive cleavage of the acyl $\mathrm{C}-\mathrm{O}$ bond and carbonyl reduction. Although much longer reaction times (and/or heating to $80{ }^{\circ} \mathrm{C}$ ) were required to achieve appreciable dihydrosilylation conversions for $i$-PrOAc, PhOAc, and $t$-BuOAc, the reduction of EtOAc into a 9:1 ratio of $\mathrm{PhSi}(\mathrm{OEt})_{3}$ and $\mathrm{PhSiH}(\mathrm{OEt})_{2}$ had reached completion after 5.5 hours (Scheme 3$){ }^{7}$ Although this reaction proceeded much slower $\left(\mathrm{TOF}=18 \mathrm{~h}^{-1}\right)$ than the ester dihydrosilylation reactions reported by Cutler and coworkers (TOF up to $227 \mathrm{~h}^{-1}$ ), ${ }^{10}$ it should be noted that $\left(\mathrm{PPh}_{3}\right)(\mathrm{CO})_{4} \mathrm{MnC}(\mathrm{O}) \mathrm{Me}$ has not been found to catalyze the cleavage of ester acyl $\mathrm{C}-\mathrm{O}$ bonds. 


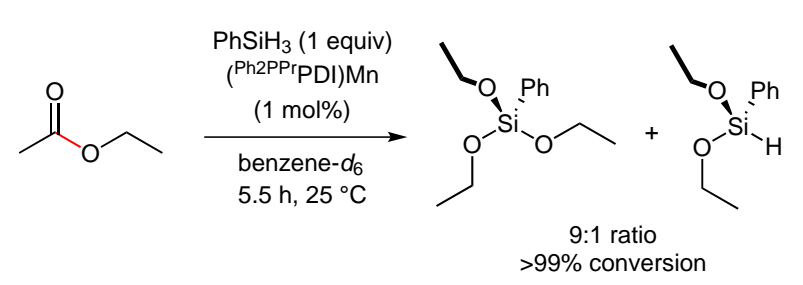

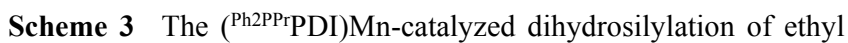
acetate; the reductively cleaved ester $\mathrm{C}-\mathrm{O}$ bond is shown in red

While the ambient temperature ester dihydrosilylation activities achieved for $\left({ }^{\mathrm{Ph} 2 \mathrm{PP} P} \mathrm{PDI}\right) \mathrm{Mn}$ are relatively modest, this complex remains the most active mangenese-based ketone hydrosilylation catalyst described to date (Table 1). Furthermore, the ketone hydrosilylation activities

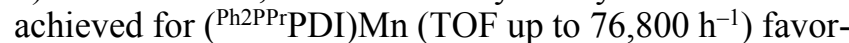
ably compare to those reported for other late first-row metal hydrosilylation catalysts. Many iron-based precatalysts that mediate this transformation operate efficiently at $23^{\circ} \mathrm{C}$ and those featuring the most impressive reported activities include $\left[\kappa^{2}-N\right.$-phosphinoamidinate) $\mathrm{Fe}\left(\mathrm{N}\left(\mathrm{SiMe}_{3}\right)_{2}\right] \quad$ (TOF up to $\left.23,600 \mathrm{~h}^{-1}\right),{ }^{26}$ $\mathrm{Fe}\left[\mathrm{N}\left(\mathrm{SiMe}_{3}\right]_{2}\right)_{2}$ (TOF up to $\left.2,400 \mathrm{~h}^{-1}\right),{ }^{27}$ (Cy PDI)Fe(Ns) $\left(\mathrm{Ns}=\right.$ neosilyl; TOF up to $\left.333 \mathrm{~h}^{-1}\right),{ }^{28}$ (iPrPybox)Fe(Ns) and $\left({ }^{\mathrm{i} P r} \mathrm{Box}\right) \mathrm{Fe}(\mathrm{Ns})_{2}$ (TOF up to $333 \mathrm{~h}^{-1}$ ). ${ }^{29}$ In contrast, cobalt-based carbonyl hydrosilylation catalysts have been found to operate with relatively poor TOF. For example, $\left[\mathrm{Co}(\mathrm{py})_{6}\right]\left[\mathrm{BPh}_{4}\right]$ remains the most active cobalt catalyst for ketone hydrosilylation at low temperatures $\left(0-20^{\circ} \mathrm{C}\right.$; TOF of $\left.11 \mathrm{~h}^{-1}\right)^{30}$ while attaining aldehyde hydrosilylation TOF of up to $50 \mathrm{~h}^{-1}$ with a cobalt(III) hydride complex required heating to $40{ }^{\circ} \mathrm{C} .{ }^{31}$ Nickel catalysts have achieved carbonyl hydrosilylation TOF of $225 \mathrm{~h}^{-1}$ (for a PCP-supported nickel hydride complex) ) $^{32}$ and $388 \mathrm{~h}^{-1}$ [for (Cp)NiH(NHC) $]^{33}$ at $23-25^{\circ} \mathrm{C}$; however, both catalysts are significantly more effective for aldehyde reduction than ketone reduction.

In summary, my colleagues and I have found that $\left({ }^{\text {P22PPr }}\right.$ PDI)Mn catalyzes the ambient-temperature hydrosilylation of carbonyl groups with activities that are ca. $3 \times$ higher than the most active iron catalyst ${ }^{26}>1500 \times$ higher than the most active cobalt catalysts, ${ }^{30,31}$ and ca. $200 \times$ higher than the most active nickel catalyst reported to date. ${ }^{33} \mathrm{We}$ are currently working to determine the mechanism of this transformation while seeking to expand upon the range of substrates that can be effectively reduced. Additionally, we hope to determine how the redox noninnocence and pentadentate coordination of ${ }^{\mathrm{Ph} 2 \mathrm{PP} P \mathrm{PDI}}$ allows for efficient manganese-mediated ketone hydrosilylation so that these design characteristics can be applied to a number of first-row-metal-mediated transformations. ${ }^{34}$

\section{Acknowledgment}

This work was supported as part of the Center for Bio-Inspired Solar Fuel Production, an Energy Frontier Research Center funded by the U.S. Department of Energy, Office of Science, Basic Energy Sciences under Award Number DE-SC0001016.

\section{References}

(1) Enthaler, S.; Junge, K.; Beller, M. Angew. Chem. Int. Ed. 2008, $47,3317$.

(2) (a) Gaillard, S.; Renaud, J.-L. ChemSusChem 2008, 1, 505. (b) Troegel, D.; Stohrer, J. Coord. Chem. Rev. 2011, 255 , 1440.

(3) Bullock, R. M. Catalysis without Precious Metals; WileyVCH: Weinheim, 2010.

(4) Haynes, W. M. CRC Handbook of Chemistry and Physics: A Ready-Reference Book of Chemical and Physical Data; Taylor and Francis: Boca Raton, 2013, 94th ed..

(5) For examples, see: (a) Zhang, W.; Loebach, J. L.; Wilson, S. R.; Jacobsen, E. N. J. Am. Chem. Soc. 1990, 112, 2801. (b) Fürstner, A.; Majima, K.; Martin, R.; Krause, H.; Kattnig, E.; Goddard, R.; Lehmann, C. W. J. Am. Chem. Soc. 2008, 130, 1992. (c) Czaplik, W. M.; Mayer, M.; Cvengroš, J.; von Wangelin, A. J. ChemSusChem 2009, 2, 396.

(d) Fürstner, A. Angew. Chem. Int. Ed. 2009, 48, 1364.

(e) Morris, R. H. Chem. Soc. Rev. 2009, 38, 2282. (f) Chen, M. S.; White, M. C. Science 2010, 327, 566.

(6) (a) Speier, J. L.; Webster, J. A.; Barnes, G. H. J. Am. Chem. Soc. 1957, 79, 974. (b) Hitchcock, P. B.; Lappert, M. F.; Warhurst, N. J. W. Angew. Chem., Int. Ed. Engl. 1991, 30, 438.

(7) Mukhopadhyay, T. K.; Flores, M.; Groy, T. L.; Trovitch, R. J. J. Am. Chem. Soc. 2014, 136, 882.

(8) Pratt, S. L.; Faltynek, R. A. J. Organomet. Chem. 1983, 258, C5.

(9) Hilal, H. S.; Abu-Eid, M.; Al-Subu, M.; Khalaf, S. J. Mol. Catal. 1987, 39, 1.

(10) Mao, Z.; Gregg, B. T.; Cutler, A. R. J. Am. Chem. Soc. 1995, 117,10139 ; as part of this effort, $(\mathrm{CO})_{5} \mathrm{MnC}(\mathrm{O}) \mathrm{Me}$, $(\mathrm{CO})_{5} \mathrm{MnMe}$, and $(\mathrm{CO})_{5} \mathrm{MnBr}$ were found to catalyze ester hydrosilylation, albeit less efficiently than $\left(\mathrm{PPh}_{3}\right)(\mathrm{CO})_{4} \mathrm{MnC}(\mathrm{O}) \mathrm{Me}$.

(11) Cavanaugh M. D., Gregg B. T., Cutler A. R.; Organometallics; 1996, 15: 2764; as part of this study, $(\mathrm{CO})_{5} \mathrm{MnC}(\mathrm{O}) 4-\mathrm{C}_{6} \mathrm{H}_{4} \mathrm{Me},(\mathrm{CO})_{5} \mathrm{MnC}(\mathrm{O}) \mathrm{Me},(\mathrm{CO})_{5} \mathrm{MnMe}$, and $(\mathrm{CO})_{5} \mathrm{MnBr}$ were found to catalyze ketone hydrosilylation far less efficiently than $\left(\mathrm{PPh}_{3}\right)(\mathrm{CO})_{4} \mathrm{MnC}(\mathrm{O}) \mathrm{Me}$.

(12) Hanna, P. K.; Gregg, B. T.; Cutler, A. R. Organometallics 1991, 10, 31 .

(13) Cavanaugh, M. D.; Gregg, B. T.; Chiulli, R. J.; Cutler, A. R. J. Organomet. Chem. 1997, 547, 173.

(14) Mao, Z.; Gregg, B. T.; Cutler, A. R. Organometallics 1998, 17, 1993.

(15) Son, S. U.; Paik, S.-J.; Lee, I. S.; Lee, Y.-A.; Chung, Y. K.; Seok, W. K.; Lee, H. N. Organometallics 1999, 18, 4114.

(16) Son, S. U.; Paik, S.-J.; Chung, Y. K. J. Mol. Catal. A: Chem. 2000, 151, 87.

(17) Igarashi, M.; Fuchikami, T. Tetrahedron Lett. 2001, 42, 1945.

(18) The slow conversion of DMF into $\mathrm{Me}_{3} \mathrm{~N}\left(\leq 1 \mathrm{~h}^{-1}\right)$ has also been achieved using $\left(\eta^{5}-\mathrm{C}_{5} \mathrm{H}_{5}\right) \mathrm{Mn}(\mathrm{CO})_{3}$ at $120^{\circ} \mathrm{C}$. See: Arias-Ugarte, R.; Sharma, H. K.; Morris, A. L. C.; Pannell, K. H. J. Am. Chem. Soc. 2012, 134, 848.

(19) Zheng, J.; Chevance, S.; Darcel, C.; Sortais, J.-B. Chem. Commun. 2013, 49, 10010.

(20) Chidara, V. K.; Du, G. Organometallics 2013, 32, 5034

(21) Schroeder, M. A.; Wrighton, M. S. J. Am. Chem. Soc. 1976, 98, 551.

(22) Bart, S. C.; Lobkovsky, E.; Chirik, P. J. J. Am. Chem. Soc. 2004, 126, 13794.

(23) Trovitch, R. J.; Lobkovsky, E.; Bill, E.; Chirik, P. J. Organometallics 2008, 27, 1470. 
(24) (a) de Bruin, B.; Bill, E.; Bothe, E.; Weyhermüller, T.; Wieghardt, K. Inorg. Chem. 2000, 39, 2936.

(b) Knijnenburg, Q.; Gambarotta, S.; Budzelaar, P. H. M. Dalton Trans. 2006, 5442.

(25) Ben-Daat, H.; Hall, G. B.; Groy, T. L.; Trovitch, R. J. Eur. J. Inorg. Chem. 2013, 4430.

(26) Ruddy, A. J.; Kelly, C. M.; Crawford, S. M.; Wheaton, C. A.; Sydora, O. L.; Small, B. L.; Stradiotto, M.; Turculet, L. Organometallics 2013, 32, 5581.

(27) Yang, J.; Tilley, T. D. Angew. Chem. Int. Ed. 2010, 49, 10186.

(28) Tondreau, A. M.; Lobkovsky, E.; Chirik, P. J. Org. Lett. 2008, 10, 2789.

(29) Tondreau, A. M.; Darmon, J. M.; Wile, B. M.; Floyd, S. K.; Lobkovsky, E.; Chirik, P. J. Organometallics 2009, 28, 3928.
(30) Brunner, H.; Amberger, K. J. Organomet. Chem. 1991, 417, C63.

(31) Niu, Q.; Sun, H.; Li, X.; Klein, H.-F.; Flörke, U. Organometallics 2013, 32, 5235.

(32) Chakraborty, S.; Krause, J. A.; Guan, H. Organometallics 2009, $28,582$.

(33) Bheeter, L. P.; Henrion, M.; Brelot, L.; Darcel, C.; Chetcuti, M. J.; Sortais, J.-B.; Ritleng, V. Adv. Synth. Catal. 2012, $354,2619$.

(34) We recently reported the preparation of $\alpha$-diimine-ligated $\mathrm{Ni}$ complexes that mediate ketone and alkyne hydrosilylation based on the methodology described herein: Porter, T. M.; Hall, G. B.; Groy, T. L.; Trovitch, R. J. Dalton Trans. 2013, $42,14689$.

Graphical Abstract

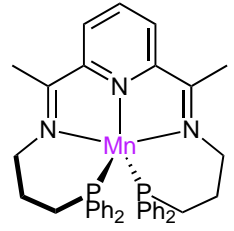

catalyzes ketone hydrosilylation with TOFs of up to $76,800 \mathrm{~h}^{-1}$

(Ph2PPrPDI)Mn

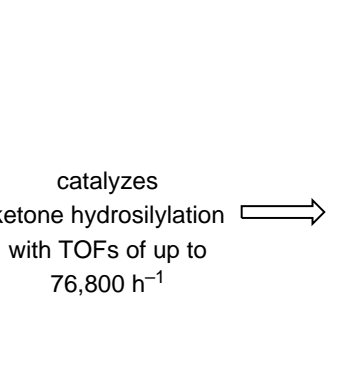

